\title{
Proceeding Paper \\ Evaluation of Functional and Nutritional Properties of Hydrolyzed Broad Bean and Quinoa Flours ${ }^{\dagger}$
}

\author{
Ileana de los A. Gremasqui, Maria A. Giménez, Manuel O. Lobo and Norma C. Sammán *(D)
}

Citation: Gremasqui, I.d.l.A.; Giménez, M.A.; Lobo, M.O.; Sammán, N.C. Evaluation of Functional and Nutritional Properties of Hydrolyzed Broad Bean and Quinoa Flours. Biol. Life Sci. Forum 2021, 8, 12. https:/ / doi.org/10.3390/blsf2021008012

Academic Editors: Loreto Muñoz and Claudia Monica Haros

Published: 18 February 2022

Publisher's Note: MDPI stays neutral with regard to jurisdictional claims in published maps and institutional affiliations.

Copyright: (C) 2022 by the authors. Licensee MDPI, Basel, Switzerland. This article is an open access article distributed under the terms and conditions of the Creative Commons Attribution (CC BY) license (https:// creativecommons.org/licenses/by/ $4.0 /)$.

\author{
Centro de Investigación Interdisciplinario en Tecnología y Desarrollo Social del NOA (CIITED), Consejo Nacional \\ de Investigaciones Científicas y Técnicas (CONICET), Facultad de Ingeniería, Universidad Nacional de Jujuy, \\ Italo Palanca 10, Jujuy CP 4600, Argentina; ileanagremasqui96@gmail.com (I.d.1.A.G.); \\ malejandragimenez@gmail.com (M.A.G.); mlobo958@gmail.com (M.O.L.) \\ * Correspondence: normasamman@gmail.com \\ + Presented at the III Conference la ValSe-Food and VI Symposium Chia-Link Network, Online, \\ 15-17 November 2021.
}

\begin{abstract}
In sports nutrition, protein intake is essential to stimulate protein synthesis and repair muscle damage caused by exercise. The search for non-traditional protein sources has increased in recent years. Quinoa (Chenopodium quinoa Wild) and broad beans (Vicia faba L.) grains could be used in the production of protein products. Broad beans are an introduced and widely expanded crop in South America; it is part of the Argentine Northwest Andean population diet. The aim of this work was to evaluate the functional and nutritional properties of hydrolyzed quinoa (HQF) and broad bean (HBF) flours for their use in the elaboration of protein foods for athletes. Both hydrolyzed flours were obtained using Flavourzyme at $50{ }^{\circ} \mathrm{C}$ and $\mathrm{pH} 8$ for 3 and $1 \mathrm{~h}$, respectively. HQF presented a higher degree of hydrolysis (21.79\%), while HBF had higher protein content $(57.31 \%)$, yield (32.14\%), and protein recovery $(71.31 \%)$. In $\mathrm{HBF}$ and $\mathrm{HQF}, \mathrm{Na}$ and $\mathrm{K}$ were the most abundant minerals, both necessary for the replacement of electrolytes lost during physical training. HBF and HQF presented 5909.63 and $2708.91 \mathrm{mg} / 100 \mathrm{~g}$ of properties, respectively, and HQF presented higher emulsifying branched amino acids content, essential in sports nutrition. Regarding technological activity $\left(61.30 \mathrm{~m}^{2} / \mathrm{g}\right)$, stability indexes (158.6 min), and foaming capacity (131\%); HBF shows a wider range of solubility in function of $\mathrm{pH}$, and good foaming stability $(68-92 \%)$. These results indicate that HQF and HBF could be potential ingredients for athletes' protein supplements formulation.
\end{abstract}

Keywords: broad beans; flour; functional properties; hydrolysis; nutritional properties; quinoa

\section{Introduction}

In sports nutrition, the consumption of hydrolyzed protein supplements has gained relevance due to their ability to modulate the anabolism of skeletal muscle proteins, improve sports performance, influence the control of body mass, and accelerate the digestion and absorption of proteins, increasing the availability of amino acids [1]. These products are obtained from protein concentrates or isolates by enzymatic hydrolysis. Obtaining hydrolysates from vegetable flours could provide advantages in the functional and nutritional properties of the product obtained due to the presence of fibers and minerals in the flours [2]. The organoleptic quality can also be improved, due to significant changes in taste. The food industry is in search of alternative protein sources. Broad beans (Vicia faba L.) are an introduced and widely expanded crop in South America; it is part of the Argentine Northwest Andean population diet and quinoa (Chenopodium quinoa Wild) is one of the most nutritive Andean grains. Due to their properties, quinoa (Chenopodium quinoa Wild) and broad beans (Vicia faba L.) grains could be used in the production of these protein products. The aim of this work was to evaluate the functional and nutritional properties of hydrolyzed quinoa (HQF) and broad bean (HBF) flours for their use in the elaboration of protein foods for athletes. 


\section{Materials and Methods}

\subsection{Materials}

Broad bean (BF) (Vicia faba L.) and quinoa (QF) (Chenopodium quinoa Wild) flours were provided by producers from Quebrada de Humahuaca, Jujuy. Quinoa flour was previously defatted.

\subsection{Obtaining Hydrolyzed Flours and Degree of Hydrolysis (DH)}

The hydrolyzed flours were prepared according to Lee et al. [3]. The enzyme used was Flavourzyme (Sigma Aldrich, St. Louis, MO, USA, 25 LAPU/g proteins) at $50{ }^{\circ} \mathrm{C}$, $\mathrm{pH} 8,1$ and $3 \mathrm{~h}$ for $\mathrm{BF}$ and $\mathrm{QF}$, respectively. The mixtures obtained were centrifuged at $4500 \times \mathrm{g} / 30 \mathrm{~min}$. The enzymes were inactivated at $85^{\circ} \mathrm{C}$ and then the $\mathrm{pH}$ was adjusted to 7 . The degree of hydrolysis was determined with trichloroacetic acid (TCA). The supernatants were dried at low temperature and ground to a particle size $<149 \mu \mathrm{m}$.

\subsection{Performance Parameters and Chemical and Nutritional Properties}

Mass yield and protein recovery were determined according to Noman et al. [4]. AOAC (2017) methods were used to determine the content of proteins, lipids, ash, soluble dietary fiber, and minerals. For soluble sugars, the method of Dubois et al. [5] method was used, and for amino acids, the method of Mota et al. [6].

\subsection{Functional Properties of Hydrolyzed Flours}

Protein solubility, emulsifying activity index (EAI), emulsion stability index (ESI), foaming capacity (FC) and foaming stability (FS) were determined in hydrolyzed flour according to Gremasqui et al. [7].

\subsection{Statistical Analysis}

The INFOSTAT program was used for the analysis of variance of the data and Fisher's LSD to compare the means with a significance level of 0.05 .

\section{Results and Discussion}

\subsection{Degree of Hydrolysis (DH)}

The DH values of HBF and HQF are shown in Table 1. The lower DH obtained in HBF could be due to the shorter hydrolysis time used and the release of larger peptides insoluble in TCA. According to Barac et al. [8], hydrolysates with $\mathrm{DH}>10 \%$ are characterized by good nutritive values.

Table 1. Performance parameters and nutritional composition of HBF and HQF.

\begin{tabular}{lcc}
\hline Parameters $^{\#}$ & HBF & HQF \\
\hline DH & $12.57 \pm 0.96^{\mathrm{a}}$ & $21.79 \pm 0.78^{\mathrm{b}}$ \\
Mass yield & $32.80 \pm 0.93^{\mathrm{b}}$ & $21.03 \pm 1.22^{\mathrm{a}}$ \\
Protein recovery & $71.32 \pm 2.03^{\mathrm{b}}$ & $67.28 \pm 1.73^{\mathrm{a}}$ \\
\hline Protein content & $57.31 \pm 0.27^{\mathrm{b}}$ & $54.69 \pm 0.12^{\mathrm{a}}$ \\
Lipids content & $0.004 \pm 0.000^{\mathrm{a}}$ & $0.003 \pm 0.000^{\mathrm{a}}$ \\
Ash content & $11.79 \pm 0.24^{\mathrm{a}}$ & $14.11 \pm 0.28^{\mathrm{b}}$ \\
SDF & $10.56 \pm 0.41^{\mathrm{a}}$ & $23.18 \pm 0.74^{\mathrm{b}}$ \\
$\mathrm{HC}$ dig. & 20.34 & 8.02 \\
Soluble sugars & $9.95 \pm 0.87^{\mathrm{a}}$ & $9.35 \pm 0.89^{\mathrm{a}}$ \\
Na & $2376.35 \pm 39.60^{\mathrm{a}}$ & $3121.96 \pm 11.65^{\mathrm{b}}$ \\
$\mathrm{Cu}$ & & $2.18 \pm 0.18^{\mathrm{a}}$ \\
$\mathrm{Fe}$ & & $20.25 \pm 0.44^{\mathrm{b}}$ \\
$\mathrm{Zn}{ }^{*}$ & $2.18 \pm 1.04^{\mathrm{a}}$ & $7.45 \pm 0.57^{\mathrm{a}}$ \\
$\mathrm{Ca}$ & $18.04 \pm 3.44^{\mathrm{a}}$ & $130.46 \pm 1.60^{\mathrm{a}}$ \\
\hline
\end{tabular}


Table 1. Cont.

\begin{tabular}{lcc}
\hline Parameters $^{\#}$ & HBF & HQF \\
\hline $\mathrm{Mg}^{*}$ & $344.27 \pm 1.99^{\mathrm{b}}$ & $180.27 \pm 7.58^{\mathrm{a}}$ \\
$\mathrm{K}^{*}$ & $3526.42 \pm 195.20^{\mathrm{a}}$ & $4000.27 \pm 135.70^{\mathrm{b}}$ \\
\hline
\end{tabular}

\# The values correspond to means \pm deviations and are expressed in (g/100 g db), $\mathrm{n}=3 ;{ }^{*} \mathrm{mg} / 100 \mathrm{~g} \mathrm{db}$. Different letters in each row are significantly different $(p<0.05)$.

\subsection{Performance Parameters and Nutritional Composition}

The mass yield, protein recovery, and chemical and nutritional composition of hydrolyzed flours are shown in Table 1. HBF had higher mass yield and protein recovery than HQF $(p<0.05)$ due to their higher natural bean protein content; this agrees with the results found by Thamnarathip et al. [9]. The high protein content of hydrolyzed flours $(>50 \%)$ makes them useful to be incorporated into sports foods. Soluble dietary fiber (SDF) content was significantly different $(p<0.05)$ between both hydrolyzed flours.

$\mathrm{Na}$ and $\mathrm{K}$ were the most abundant minerals in both hydrolyzed flours, both necessary for the replacement of electrolytes lost during physical training [10]. According to Xia et al. [10], minerals such as $\mathrm{Fe}, \mathrm{Zn}$, and $\mathrm{Mg}$ also stand out for their usefulness for an athlete's nutrition. A portion of $30 \mathrm{~g}$ of these hydrolyzed flours would contribute between $73 \%$ to $76 \%$ of the recommended protein dose (20-25 g) to stimulate muscle protein synthesis after exercise [1]; $12-25 \%$ of suggested fiber dietary intake (25-30 g/day); approximately $48-62 \%$ and $53-60 \%$ of $\mathrm{Na}$ and K RDI, respectively, for athletes.

Table 2 shows the total and free amino acid composition of hydrolyzed flours. The total essential amino acid content was 6415.13 and $11901.71 \mathrm{mg} / 100 \mathrm{~g}$ of HQF and HBF, respectively. The predominant essential amino acids were leucine, lysine, and valine; these results agree with Muhamyankaka et al. [2]. HBF and HQF presented high contents of branched amino acids, essential in sports nutrition to improve sports performance by reducing the appearance of fatigue. Both hydrolyzed flours are rich in glutamic acid, glutamine precursor, which is important to recover muscle glycogen deposits and avoid loss of muscle mass.

Table 2. Amino acid composition of $\mathrm{HBF}$ and $\mathrm{HQF}$.

\begin{tabular}{|c|c|c|c|c|}
\hline Amino Acid (mg/100 g Sample) & $\mathrm{HBF}^{\mathrm{a}}$ & $\mathrm{HQF}^{\mathrm{a}}$ & $\mathrm{HBF}^{\mathrm{b}}$ & $\mathrm{HQF}^{\mathrm{b}}$ \\
\hline \multicolumn{5}{|l|}{ Essential amino acid } \\
\hline Histidine & $855.3 \pm 25.0^{\mathrm{b}}$ & $639.3 \pm 8.2^{\mathrm{a}}$ & $26.54 \pm 1.53^{\mathrm{a}}$ & $116.63 \pm 2.12^{b}$ \\
\hline Threonine & $1375.5 \pm 35.9^{b}$ & $760.2 \pm 3.9^{\mathrm{a}}$ & $13.54 \pm 4.35^{\mathrm{a}}$ & $27.56 \pm 2.95^{b}$ \\
\hline Valine & $1578.6 \pm 20.4^{b}$ & $837.5 \pm 1.1^{\mathrm{a}}$ & $20.04 \pm 4.57^{\mathrm{a}}$ & $41.69 \pm 4.77^{b}$ \\
\hline Methionine & $292.1 \pm 12.5^{\mathrm{a}}$ & $434.7 \pm 5.3^{\mathrm{b}}$ & $24.91 \pm 3.32^{\mathrm{a}}$ & $50.46 \pm 4.02^{b}$ \\
\hline Lysine & $1928.8 \pm 6.7^{\mathrm{b}}$ & $1024.6 \pm 10.3^{\mathrm{a}}$ & n.d & n.d \\
\hline Isoleucine & $1344.9 \pm 35.5^{b}$ & $642.1 \pm 0.2^{\mathrm{a}}$ & $15.95 \pm 0.44^{\mathrm{a}}$ & $35.78 \pm 7.07^{b}$ \\
\hline Leucine & $2986.1 \pm 78.8^{b}$ & $1229.3 \pm 1.3^{\mathrm{a}}$ & $27.19 \pm 4.06^{\mathrm{a}}$ & $99.48 \pm 4.84^{b}$ \\
\hline Phenylalanine & $1540.4 \pm 63.0^{b}$ & $847.4 \pm 1.9^{\mathrm{a}}$ & $49.48 \pm 10.81^{\mathrm{a}}$ & $149.82 \pm 2.60^{b}$ \\
\hline Tryptophan & n.d & n.d & $33.31 \pm 2.12^{\mathrm{a}}$ & $91.36 \pm 5.13^{b}$ \\
\hline \multicolumn{5}{|l|}{ Nonessential amino acid } \\
\hline Aspartic acid & $6030.4 \pm 63.4^{b}$ & $2384.3 \pm 33.1^{\mathrm{a}}$ & $206.48 \pm 2.17^{b}$ & $17.23 \pm 2.83^{\mathrm{a}}$ \\
\hline Glutamic acid & $9475.7 \pm 113.9^{b}$ & $5475.6 \pm 36.2^{a}$ & $69.26 \pm 4.72^{\mathrm{a}}$ & $87.68 \pm 7.30^{b}$ \\
\hline Serine & $2129.2 \pm 57.0^{b}$ & $1023.0 \pm 4.8^{\mathrm{a}}$ & $11.83 \pm 1.21^{\mathrm{a}}$ & $17.47 \pm 2.83^{b}$ \\
\hline Arginine & $3409.2 \pm 115.0^{b}$ & $1624.3 \pm 15.5^{\mathrm{a}}$ & $429.52 \pm 7.07^{b}$ & $41.50 \pm 0.70^{\mathrm{a}}$ \\
\hline Cysteine & $173.2 \pm 21.3^{a}$ & $179.4 \pm 8.3^{\mathrm{b}}$ & n.d & n.d \\
\hline Tyrosine & $1338.0 \pm 49.5^{b}$ & $772.5 \pm 9.7^{\mathrm{a}}$ & $40.77 \pm 0.89^{a}$ & $95.75 \pm 1.55^{b}$ \\
\hline Glycine & $1699.5 \pm 58.4^{b}$ & $1275.5 \pm 23.5^{\mathrm{a}}$ & $22.65 \pm 3.62^{a}$ & $35.80 \pm 0.69^{b}$ \\
\hline Alanine & $1921.6 \pm 23.4^{b}$ & $1139.5 \pm 7.5^{\mathrm{a}}$ & $46.81 \pm 1.12^{\mathrm{a}}$ & $118.95 \pm 3.07^{b}$ \\
\hline
\end{tabular}


Table 2. Cont.

\begin{tabular}{lcccc}
\hline Amino Acid (mg/100 g Sample) & HBF $^{\mathbf{a}}$ & $\mathbf{H Q F}^{\mathbf{a}}$ & HBF $^{\mathbf{b}}$ & $\mathbf{H Q F}^{\mathbf{b}}$ \\
\hline Proline & $1917.7 \pm 39.7^{\mathrm{b}}$ & $919.2 \pm 6.9^{\mathrm{a}}$ & $66.29 \pm 4.01^{\mathrm{a}}$ & $75.31 \pm 3.06^{\mathrm{b}}$ \\
Total amino acid $^{\mathrm{a}}$ & $39996.2 \pm 794.5^{\mathrm{b}}$ & $21208.5 \pm 85.5^{\mathrm{a}}$ & $1104.56 \pm 17.46^{\mathrm{b}}$ & $1102.48 \pm 8.98^{\mathrm{a}}$ \\
Taste component $^{\mathrm{c}}$ & & & & \\
Umami & & & $275.74 \pm 6.89^{\mathrm{b}}$ & $104.92 \pm 10.13^{\mathrm{a}}$ \\
Sweet $_{\text {Bitter }}$ & & $501.69 \pm 2.63^{\mathrm{b}}$ & $205.48 \pm 2.25^{\mathrm{a}}$ \\
\hline
\end{tabular}

${ }^{a}$ Total amino acid content, ${ }^{b}$ Free amino acid content, ${ }^{c}$ Umami taste: Glu + Asp; Sweet taste: Ala + Arg + Ser + Thr; Bitter taste: Gly + His + Ile + Leu + Met + Phe + Val + Pro; n.d: not detected.

HBF was rich in free arginine (38.88\%) and aspartic acid (18.69\%), while HQF was rich in free phenylalanine $(13.60 \%)$, alanine $(10.80 \%)$, histidine $(10.57 \%)$, and leucine $(9.02 \%)$; these results are similar to those found by Laohakunjit et al. [11]. The free amino acids would significantly affect the taste characteristics of hydrolyzed flours. HBF had the highest amount of umami and sweet amino acids, whereas HQF had the highest content of bitter amino acids.

\subsection{Functional Properties}

Protein solubility. Figure 1 shows HBF and HQF protein solubility. HBF showed significantly higher solubility and a greater range of variation with the $\mathrm{pH}(65.10-87.54 \%)$ than HQF $(p<0.05)$. The minimum protein solubility was at $\mathrm{pH} 4(16.22$ and $33.77 \%$ for $\mathrm{HBF}$ and HQF, respectively). The higher protein solubility in HBF could be due to its greater exposure of polar amino acid that interacts with water through hydrogen bonding. The inconsistency between the lower DH and higher solubility in HBF could be due to the balance between hydrophilic and hydrophobic forces scores over $\mathrm{DH}$.

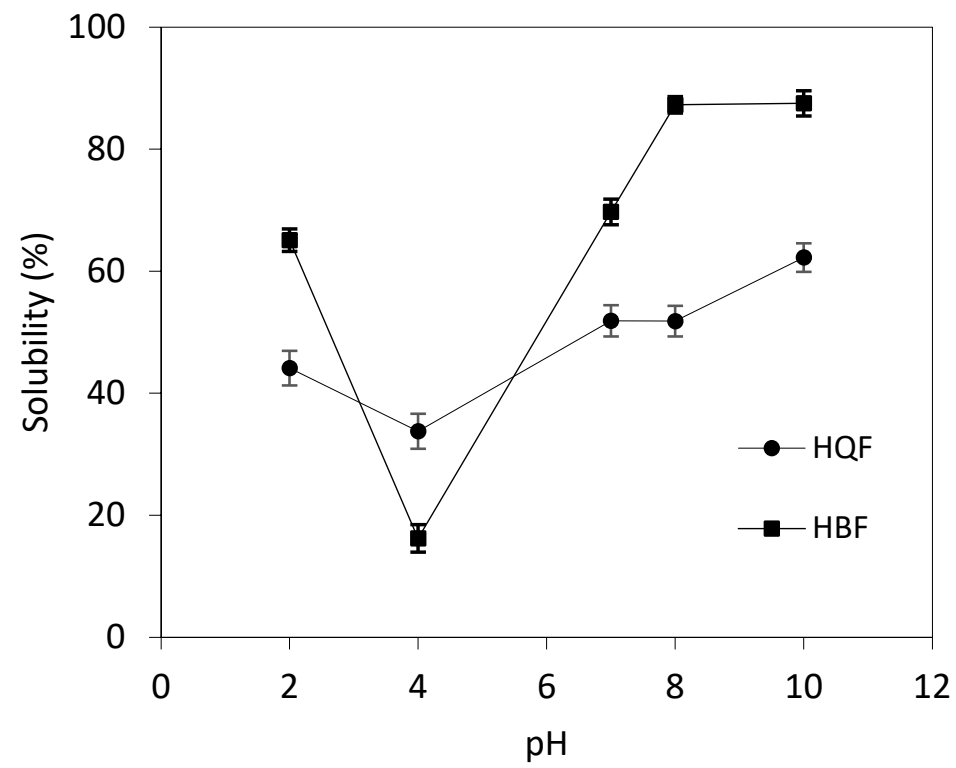

Figure 1. Protein solubility of $\operatorname{HBF}(\boldsymbol{\square})$ and $\operatorname{HQF}(\bullet)$ as a function of $\mathrm{pH}$.

Emulsifying properties. HQF presented better surfactant properties than $\operatorname{HBF}(p<0.05)$ (Table 3). The lower EAI and ESI values in HBF could be due to the lower DH and a higher exposure of hydrophilic groups that would bind with peptides in the aqueous phase, decreasing hydrophobicity and emulsifying stability [12]. 
Table 3. Functional properties of HBF and HQF.

\begin{tabular}{lcc}
\hline Functional Properties & HBF $^{\#}$ & HQF $^{\#}$ \\
\hline EAI $\left(\mathrm{m}^{2} / \mathrm{g}\right)$ & $38.57 \pm 1.45^{\mathrm{a}}$ & $61.30 \pm 0.14^{\mathrm{b}}$ \\
ESI $(\mathrm{min})$ & $55.01 \pm 3.56^{\mathrm{a}}$ & $158.60 \pm 1.70^{\mathrm{b}}$ \\
FC $(\%)$ & $89.50 \pm 6.36^{\mathrm{a}}$ & $131.00 \pm 4.24^{\mathrm{b}}$ \\
\hline
\end{tabular}

\# The values correspond to means \pm standard deviations, $\mathrm{n}=3$. Different letters in each row indicate significant differences $(p<0.05)$.

Foaming properties. According to the results shown in Table 3, HQF has the highest $\mathrm{CF}$ value, probably due to the higher $\mathrm{DH}$ responsible for a greater number of small peptides that are easily adsorbed at the air-water interface [2]. Figure 2 shows the stability of the foam (FS). HBF and HQF showed significant differences $(p<0.05)$ after $10 \mathrm{~min}, \mathrm{HBF}$ showing better FS [12].

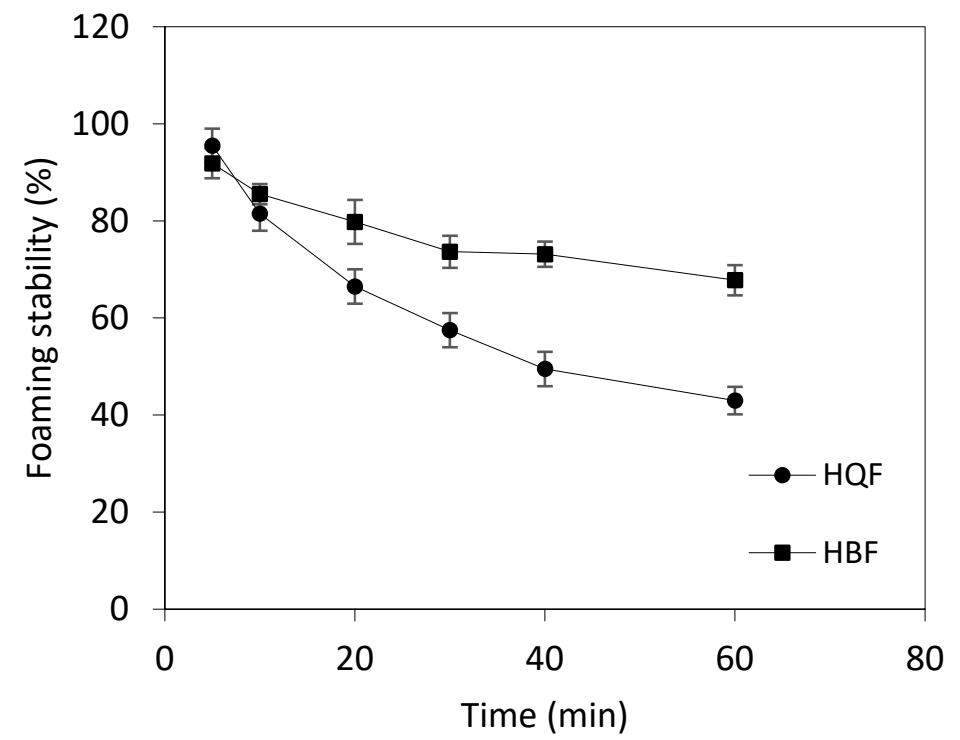

Figure 2. Foaming stability of $\operatorname{HBF}(\boldsymbol{\square})$ and $\operatorname{HQF}(\bullet)$ as a function of time.

\section{Conclusions}

The enzymatic hydrolysis of quinoa and broad bean flours has been an adequate way to improve the nutritional properties (high protein content and good source of essential and branched amino acids), making them suitable as ingredients in the preparation of food for athletes. HBF and HQF were characterized by having higher levels of free amino acids that produce sweet and sour tastes. On the other hand, the hydrolyzed products presented high solubility and good surfactant properties, which is why they could be used in the preparation of beverages, creams, butter, ice cream, mousses, and cakes. The enzymatic hydrolysis applied directly to the flours caused a positive effect on the nutritional and functional properties.

Author Contributions: Conceptualization, and methodology, I.d.l.A.G. and M.A.G.; validation I.d.l.A.G., M.A.G., M.O.L. and N.C.S.; formal analysis, I.d.l.A.G. and M.A.G.; investigation, I.d.l.A.G. and M.A.G.; resources, M.O.L. and N.C.S.; data curation, I.d.l.A.G.; writing—original draft preparation, I.d.l.A.G.; writing-review and editing, M.A.G., M.O.L. and N.C.S.; visualization, I.d.l.A.G.; supervision, M.A.G., M.O.L. and N.C.S.; project administration, M.O.L. and N.C.S.; funding acquisition, M.O.L. and N.C.S. All authors have read and agreed to the published version of the manuscript.

Funding: This research received no externa funding.

Institutional Review Board Statement: Not applicable.

Informed Consent Statement: Not applicable. 
Data Availability Statement: Not applicable.

Acknowledgments: This work was supported by grant Ia ValSe-Food-CYTED (Projet No 119RT0567) and SECTER-Universidad Nacional de Jujuy-CONICET.

Conflicts of Interest: The authors declare no conflict of interest.

\section{References}

1. de Antuñano, N.P.G.; Marqueta, P.M.; Redondo, R.B.; Fernández, C.J.C.; de Teresa Galván, C.; del Valle Soto, M.; Bonafonte, L.F.; Gabarra, A.G.; Gaztañaga, T.A.; Manonelles, P.M.; et al. Suplementos nutricionales para el deportista. Ayudas ergogénicas en el deporte-2019. Documento de consenso de la Sociedad Española de Medicina del Deporte. Arch. Med. Deporte 2019, $36,1-114$.

2. Muhamyankaka, V.; Shoemaker, C.F.; Nalwoga, M.; Zhang, X.M. Physicochemical properties of hydrolysates from enzy-matic hydrolysis of pumpkin (Cucurbita moschata) protein meal. Int. Food Res. J. 2013, 20, 2227-2240.

3. Lee, J.-Y.; Lee, H.D.; Lee, C.-H. Characterization of hydrolysates produced by mild-acid treatment and enzymatic hydrolysis of defatted soybean flour. Food Res. Int. 2001, 34, 217-222. [CrossRef]

4. Noman, A.; Qixing, J.; Xu, Y.; Ali, A.; Al-Bukhaiti, W.Q.; Abed, S.M.; Xia, W. Influence of Degree of Hydrolysis on Chemical Composition, Functional Properties, and Antioxidant Activities of Chinese Sturgeon (Acipenser sinensis) Hydrolysates Obtained by Using Alcalase 2.4 L. J. Aquat. Food Prod. Technol. 2019, 28, 583-597. [CrossRef]

5. Dubois, M.; Gilles, K.A.; Hamilton, J.K.; Rebers, P.A.; Smith, F. Colorimetric Method for Determination of Sugars and Related Substances. Anal. Chem. 1956, 28, 350-356. [CrossRef]

6. Mota, C.; Santos, M.; Mauro, R.; Samman, N.; Matos, A.S.; Torres, D.; Castanheira, I. Protein content and amino acids profile of pseudocereals. Food Chem. 2014, 193, 55-61. [CrossRef] [PubMed]

7. Gremasqui, I.A.; Giménez, M.A.; Lobo, M.O.; Sammán, N.C. Nutritional and Functional characterisation of hydrolysates from quinoa flour (Chenopodium quinoa) using two proteases. Int. J. Food Sci. Technol. 2021, 56, 6507-6514. [CrossRef]

8. Barać, M.; Čabrilo, S.; Pešić, M.; Stanojević, S.; Pavlićević, M.; Maćej, O.; Ristić, N. Functional Properties of Pea (Pisum sativum, L.) Protein Isolates Modified with Chymosin. Int. J. Mol. Sci. 2011, 12, 8372-8387. [CrossRef]

9. Thamnarathip, P.; Jangchud, K.; Jangchud, A.; Nitisinprasert, S.; Tadakittisarn, S.; Vardhanabhuti, B. Extraction and characterisation of Riceberry bran protein hydrolysate using enzymatic hydrolysis. Int. J. Food Sci. Technol. 2015, 51, 194-202. [CrossRef]

10. Xia, R. Study on the Reasonable Supplement of Vitamin and Minerals for Athletes. Adv. J. Food Sci. Technol. 2015, 8, 303-305. [CrossRef]

11. Laohakunjit, N.; Kerdchoechuen, O.; Kaprasob, R.; Matta, F.B. Volatile Flavor, Antioxidant Activity and Physicochemical Properties of Enzymatic Defatted Sesame Hydrolysate. J. Food Process. Preserv. 2016, 41, e13075. [CrossRef]

12. Betancur-Ancona, D.; Martínez-Rosado, R.; Corona-Cruz, A.; Castellanos-Ruelas, A.; Jaramillo-Flores, M.E.; Chel-Guerrero, L. Functional properties of hydrolysates fromPhaseolus lunatusseeds. Int. J. Food Sci. Technol. 2008, 44, 128-137. [CrossRef] 